\title{
DOCTOR TRIXIE BEAU'S ADVICE TO THE UNINSURED
}

About three months ago a bump appeared on the bridge of my nose. It had a hard whitish tip. Naturally, I picked it, but it didn't go away. So I picked it again. The hard whitish tip came off, but then it regrew. I picked it. It regrew. I picked it. It regrew.

"My unicorn horn won't go away," I complained to my boyfriend Eliot. He told me to go to the dermatologist and get it frozen off. "But what if it's the source of all my power?" Again, I pressed down on its rough edge with my fingernail.

He rolled his eyes. "What if it's cancerous?"

I stopped picking. I've spent a lot of time in the sun.

Anxious, I called my mother to see if she could recommend a doctor. As I hung up the phone, I made a face at Eliot, who was cleaning up cat pee with a sponge. Wally had sprayed the stereo again. "Dr. Trixie Beau?" I said. "What kind of name is that for a dermatologist? Dr. Trixie Beau? What does she do, wrangle horses in her spare time?"

"Just call her."

But before I called Dr. Trixie Beau, I looked her up online. Dr. Trixie Beau's website featured a large glowing portrait of Dr. Trixie Beau with a grinning, dimpled preteen whom I presumed was Dr. Trixie Beau's daughter. Both of them had impeccable, smooth skin. Feathery white script unspooled above their shining heads: Look Good at Any Age...

"I resent her already," I said.

Eliot aimed the spray bottle of Nature's Promise Odor Removal at the speakers. "Call her, Jane."

I didn't have to wait long at Dr. Trixie Beau's office. Within minutes, I was whisked into one of the dermatologist's procedural rooms, and Dr. Trixie Beau herself stepped through the door, in a rush of perfumed air, her coppery hair perfectly coiffed.

"Hmmm," she murmured, staring between my eyes at my bump. "A subcutaneous horn."

"A subcutaneous horn?" 
"It's going to need to be removed and biopsied." She reached for a pair of plastic gloves then opened the door of the procedural room and called for her assistant. The assistant rushed in and stood at the ready with a clipboard and pen. "Often when the subcutaneous horn growth is present on the bridge there is possibility for intracethalmusola which can be stimulated by the terninoctic manatinis of the nose compacted by the presence of sun damage and external cenomatatosis," Dr. Trixie Beau said.

She was coming at me with a needle. I shut my eyes.

"The ectoplasma of the ciliacosis can cause regrowth doubled by the presence of natatoriul plasmapheresis. So we're going to cover all our bases here." There was a piercing pain and I winced. "Now I'm going to remove the growth, but you won't feel anything." I opened my eyes quickly to see her putting down the needle and reaching for a small scalpel. I shut my eyes again and gripped the arms of the chair. "Okay, all done." She removed her gloves with a snap and gave me a cursory smile. "We'll give you a call about the biopsy results in a couple days." She was out the door.

"Dr. Beau?" I called. Dr. Trixie Beau paused, her one leg already into the hallway. "I'm sorry, but what's a subcutaneous horn?"

She pointed at her assistant. "Heather will explain everything."

"Is it a skin cancer?"

"Possibly. A cancer or a precancerous growth. We won't know until we get the results." She gave me a tight smile and headed into the hallway and into the next room where another patient waited. After Heather told me how to treat my biopsy site, I walked to the front desk.

Another brunette with impeccable skin gave me a bright smile. "Five hundred dollars, please," she said.

I stared at her, open-mouthed. I had been there all of seven minutes.

I first noticed the bump on my nose when I was in Massachusetts earlier that summer visiting family. Three days into this trip, I got a call from Eliot, who was still at home in Los Angeles. I presumed he was calling for our daily long-distance check-in.

"Dude!" I said, picking up the phone. "I miss you already!" My hair was still wet from a late-afternoon swim in the ocean. "How was your day?"

"Dude," he said. "Brace yourself. I have some bad news."

I frowned and sat down on the corner of my bed.

"Maxeem is gone," he said. 
"What do you mean?" I asked. Maxeem was my 1996 maroon Nissan Maxima, my trusty, dusty, and beloved means of transport for the last ten years. The last "a" in Maxima had been knocked off the trunk by an old bike rack. "What do you mean she's gone?" My mother had driven me to the airport, and I had left Maxeem parked in front of my parents' house.

"Someone stole your car, sweetie."

I fell over onto my back and stared at the wooden beams of the ceiling.

"Your dad noticed she wasn't there this morning. At first he thought your sister had borrowed her, but then he realized your sister was upstairs."

Immediately I began to try to remember what I had left in the trunk. I had returned the box of library books I had checked out for the summer course I had been teaching. But there were a couple textbooks and another box of books I was supposed to have dropped off at the Goodwill in the backseat.

My notes.

I sat up. I'd left two stacks of lecture notes for the college courses I taught in the trunk. I fell over onto my back again. It had taken me six years as an underpaid part-timer to streamline those class plans. "Shit, shit, shit."

Around the fourth time I picked the bump on my nose, Eliot and I made up our minds: we had to move. We'd been living in a Los Angeles neighborhood that real estate agents liked to call Elysian Valley, but that locals liked to call Frogtown. This could be because there once had been frogs in Frogtown-we lived a block from the trashed concrete banks of the L.A. River-or because it was Frogtown gang turf, or both. The dumpsters and abandoned warehouses at the end of our block had recently been covered with their red "FTR" graffiti, and Eliot and I were routinely awakened by police helicopters at 3 a.m., their searchlights flashing across the walls of our bedroom.

Our guesthouse was tiny, and we shared it with Bill and Wally, two longlegged black-and-white cats who existed in a constant state of territorial warfare, which equaled pee. It should be noted that their cat door was the size of a kickboard, which meant that raccoons and other feral Frogtown inhabitants frequently paid unwelcome visits, which equaled more pee. In fact, Eliot had just been aiming his bottle of Nature's Promise Odor Removal at three large yellow droplets on the side of the television one night when he heard the telltale squeak of our back gate. A police helicopter had been chopping up the air overhead for the last fifteen minutes, its searchlight right in our yard, on our tomato plants, on our steps. I was out and not expected home 
for several hours. Eliot told me later that he heard footsteps. Someone was running behind our house. Quickly he set down the spray bottle and reached for a butcher knife. Hiding it behind his back, he stepped out into the yard.

A young man in a tank top stood sweating near the back fence clutching a cell phone.

They stared each other.

Eliot pointed at the LAPD helicopter. "Is that for you?"

The young man nodded and held up his hands. "It's okay though, man. I got in a fight with my girlfriend."

"Get the fuck out of my yard."

"It's okay man. I'm a friend of Jerrod's. It's okay."

"Get the fuck out of my yard," Eliot said again. The young man leapt over the back fence and disappeared.

Our guesthouse is set behind a regular-sized house inhabited by a young family. Jerrod is the father of the family. Eliot and I do not know what Jerrod does for a living, only that he and his wife each drive a black Mercedes and that there are a lot of loitering strangers and foot traffic through and around our shared front gate.

When Eliot told Jerrod my car had been stolen, Jerrod didn't understand initially that it hadn't been stolen in Frogtown. "If I hear anything about her car," he told Eliot, commiserating. "I'll let you know."

"If he hears anything?" I asked Eliot. "Who is he hanging out with? What did he say when you told him about the guy in the yard?"

Eliot just shook his head.

Then a couple weeks later we got a call from our landlord. She said she had gotten an anonymous call claiming that the front house was a drug den. She wanted to know if we thought this was outlandish. Eliot and I exchanged looks.

"We need to move," he mouthed.

It was the icing on the cake, or as we say in Frogtown, the diaper on the lawn. I agreed wholeheartedly that we should move, but I was anxious. Eliot worked as an architect at a small firm and his hours had recently been cut. He was now at two-thirds time. I didn't know how many classes I'd be assigned to teach the next semester, if any, and we needed to take Bill and Wally to the vet to sort out the peeing problem. The irony was Eliot had recently spent over a thousand dollars curing Bill of bladder crystals. Also my 
health insurance premium had just gone up another hundred dollars I didn't have. We were both nursing fat student loans. I'd only have the rental car to replace Maxeem for the next thirty days.

But police helicopters aside, our apartment was miniscule. I was tired of grading papers on the sofa, of scheduling alternating table time with Eliot ("Why don't I sit at the kitchen table for twenty minutes and do my Internet research, and then you can sit here after"). We dreamed of having desks. Separate, large desks.

"Let's do it," I said, waiting as Eliot popped the top off his Sierra Nevada so that I could stand in the kitchen and use the cutting board.

"We won't get anything much more expensive."

"Right."

"We couldn't afford it."

Eliot set down his beer and eyed the counter. "God damn it. Wally sprayed the toaster again."

"Oy, that cat."

Eliot reached for the sponge. "I can't wait to get out of here."

"So my friend's mom's friend noticed this bump, like, just one afternoon, right?" my friend Lisa said. I wasn't sure I wanted to hear the rest of her story. I had called her at the clothing store where she worked, and she was obviously bored. I just wanted to complain a little. But this was a bad combination.

"Uh huh." I reached for the pee sponge and squatted before the kitchen cabinet.

"And the next thing she knew, she was, like, covered in these things."

"Were they called subcutaneous horns?"

"I don't know. But she was like covered in them, you know? And she, like, died a couple months after that."

"Okay, thanks. That's helpful."

"Can you believe it? Like, dead. Like that fast."

"Again, very helpful."

"I'm just saying."

I hung up as quickly as I could, then scrolled through my list of contacts for "Derm" and dialed.

"Dr. Trixie Beau's office."

"Hi, this is Jane Sandor. I'm calling about my biopsy results?" 
"Okay...let's see...Jane, I'm sorry, but those won't be ready for another week."

"Dr. Beau told me to call today. She said in two days."

"Well it's normal for them to take a week."

"But she told me today."

"Sorry. Call back in a week."

"Why would she tell me two days?"

"I have no idea."

"Will she tell me if it's cancerous over the phone?"

"Ma'am, you're going to have to call back next week."

In the Craigslist ad, the apartment building looked old, wooden, and charming, like a nineteenth-century Massachusetts farmhouse. Two bedrooms, just the outer limits of our budget. Driving to Highland Park, I smacked Eliot's knee excitedly.

"We'll drink hot cider in the fall, and I'll knit pillows for our sofa and garden and sew things!" I squealed.

Eliot squinted at the freeway exit. "Was it Forty-third Street or Fifty-third Street?"

"We could maybe even save a tiny bit of money, and Wally and Bill will stop peeing on the bookshelves, and I'll-"

Eliot pulled up in front of the chain-link fence wrapped with barbed wire. "Twenty-two forty-seven," he said. "Right?"

I recognized the building's thin blue wooden siding and the small diamond-shaped stained glass at the top of the second floor from the Craigslist photo. However, I did not recognize the two vagrants on the stoop who were passing a paper-bagged forty between them.

"Hey man!" The bearded one called to Eliot as he opened the car door. "Hey man!" He called again, stumbling toward us beyond the gate. He grinned toothlessly.

I ran my finger over the tender spot on the bridge of my nose. "It's just how I pictured it."

Eliot leaned down to peer inside the car. "Oh come on, Jane. It's not that bad."

I glanced down the street toward Figueroa. Liquor store on the southeast corner, liquor store on the northwest corner, check-cashing store on the northeast corner, Popeye's on the southwest corner. 
"Nope," I said. "Not getting out."

"We drove over here. We should at least go inside."

"Nope. Not getting out."

"Whooooo!" The vagrant at the gate wailed. I didn't look at him, but it was hard to miss his gyrating pelvis.

Eliot peered at me. "Are you-"

"Nope. Not getting out."

"Hey baby! Whoooooo!" The vagrant gripped the chain-link fence between his thick dirty fingers and shook it violently. He was fumbling for the gate latch.

"Point taken," Eliot said, jumping back into the car.

We drove down the 110 freeway in silence, air conditioning blasting.

"Craigslist can suck my unicorn horn," I said.

"The baby boomers can suck my unicorn horn," Eliot said.

"Word."

"You know what my boss said when he moved me to two-thirds time?"

I shook my head.

"I hope you have a financial cushion," Eliot said. He shook his head.

I pressed down on the tender part of my nose and shut my eyes. "I need to call Obama."

As we pulled up in front of our place in Frogtown, five young men in baggy jeans and white T-shirts were lurking beneath the avocado tree, smoking cigarettes. Eliot and I exchanged looks.

"Hi!" I called to the young men, waving vigorously while Eliot pulled the stack of bills from our mailbox. The men looked us over coldly and narrowed their eyes. We tromped across the shared lawn, carefully avoiding used baby diapers, crushed children's toys, empty soda cans, dirty Styrofoam, oily rags, and my favorite, the small deflating bouncy castle full of fetid sprinkler water, cigarette butts, and decomposing leaves. "Have a great day," I called over my shoulder. I could hear Jerrod's three-year-old wailing inside the house.

As usual our place reeked of urine, the air fetid and hot. Eliot glanced at the bills in his hand and then stared at me. I frowned. He frowned. I pressed the tender part of my nose and felt a stinging around my eyes.

"Let's use it," Eliot said softly.

I glanced at the fridge. "Really?" 
"Now. Tonight."

"Are you sure?"

Eliot walked to the refrigerator and took down the three-hundred-dollar gift certificate his boss had given him for Christmas last year. Last year before the market crashed.

He stared at it. "We could really use that cash."

"Too late," I said walking over to him and smacking his butt. "Go get changed."

An hour later Eliot and I were being served gelid triangles of perfect yellowtail offset by Japanese wafers and miniature sprigs of dill-the first of our nine courses at Providence, the two-Michelin-star restaurant on Melrose Avenue. The delicate tinkling of cutlery filled the softly luminous gray room, all the elegant white tablecloths around us punctuated by rust-colored wire candle holders. Moments later we were brought sea urchin foam in softboiled eggs held aloft by golden cups, then silver spoons cupping a frozen rectangle with a mint leaf inside: a mojito that burst into a rapturous liquid in our mouths. The sommelier came to open the wine we'd brought. Eliot began to sweat. He leaned over to me.

"It's from Trader Joe's," he whispered. "Do you think they'll notice? We should've brought something better. We should have spent a little." He looked up at the sommelier flourishing his bottle opener and napkin and smiled anxiously.

"It's okay, Eliot."

"But it was $\$ 3.99$," he whispered.

I kissed him on the cheek. "It doesn't matter."

"It's embarrassing."

"It's middle-class. It's how we roll." As the sommelier filled my glass and ducked his head obsequiously, I couldn't help but imagine the dilapidated building we'd so recently considered moving into. I glanced at the table next to ours where two couples in their sixties wearing silk, linen, and cashmere sampled house-cured sea trout. The women's fingers were loaded with diamond rings, the edges of their oddly immobile faces pulled upward, their gray-blond hair expertly coiffed. Lawyers, doctors, Mercedes drivers.

I elbowed Eliot. "Don't look now. But I think I spotted some baby boomers."

"Where are they?" Eliot snatched up his fork and brandished it menacingly. 
"Here you go," the sommelier said, gently setting down our pinot noir. He pointed at the bottle. "I'm not familiar with this pinot."

"No?" I said, stepping on Eliot's foot under the table. "It's incredible. Pricey, sure, but worth it."

They found Maxeem on a side street in downtown, her battery ripped from her rusty guts and tossed into the trunk. Totaled.

"Rip out my heart, why don't they," I moaned, throwing down my keys and pitching myself across the couch in a puff of cat hair. I glanced over at Eliot for a reaction, but he was staring at his computer screen.

"Here's a two-bedroom in Palmdale in our price range," he said.

"Whoever stole Maxeem left like three empty Big Gulps in the back seat."

"So it used to be a meth lab. Who are we to be picky?" He took a sip of his beer.

"And my ergonomic backrest was gone. And the box of old textbooks. That's what I don't get."

"How do you feel about going windowless?"

"I mean who are these thieves? Teenage bookworms with sciatica?"

My phone rang. Derm, the blue screen of my phone flashed. Derm.

"It's her." I stood.

Eliot stood.

Then I answered.

"Well, it turns out the intracethalmusola is in a stage of cenomatatosis for which neurotedermotasis will be the best course of action. What you want to avoid is more plasmapheresis."

"I don't understand," I said.

"I'm going to call in a prescription. An ointment that will reduce the possibility of increased plasmapheresis and more advanced cenomatatosis. And you need to get serious with your sunscreen."

"What are the risks here?"

"You just want to take care of this as soon as possible."

"Will it spread?"

"Just use the ointment as directed..." There were muffled sounds on Dr. Beau's end, a rattle. I could hear the half blocking of the receiver as Dr. Beau called out to her office: "Tell Livia I want turkey with no mayo and two Diet Cokes!" Shuffling. "Just use the ointment as directed." 
"What does the ointment do?"

"Just use it as directed, okay? Great! I'll call you to see how it's going next week."

"Dr. Beau?"

On our way to the twenty-four-hour cvs, Eliot said there was something else he needed to tell me. I'd noticed he'd been unusually quiet the last hour, and instinctively, I braced myself for any number of the horrible revelations I liked to imagine when feeling insecure and paranoid: he didn't love me, he'd thought my unicorn horn was repellent, he was having a secret affair with Scarlett Johansson's body double.

"We are going to have to postpone our apartment hunt."

I nodded, not completely surprised, relieved he still loved me.

"I just got an e-mail from my boss before we left the house telling me not to come in tomorrow," he added.

My mouth fell open. "What does that mean?" We couldn't make it on my salary alone, that's for sure.

He shrugged and downshifted. "There's no work. He can't pay me. He said he'd call me when we got a job."

"But you guys have designed houses for, like, movie stars! All those Hollywood schmoozers! The guy who did Saw II!"

"The schmoozers aren't building shit right now."

"Oh my God," I said. "Oh my God."

"Is the cvs left here or right?"

I stood in line under the flickering fluorescent lights of the cVs for fifteen minutes before the pharmacist went to fetch my prescription. Walking back to the counter, he held up an inch-and-a-half long tube of ointment, smaller than a travel-sized Crest.

"Put it on the biopsy spot once at night and once in the morning. Avoid the sun and wash your hands well after." He smiled. "You may experience increased redness, scarring, or even a return of the subcutaneous abnormality."

I frowned. "The horn's going to come back?"

He scanned the ointment under the red checkout laser.

"But isn't the point that it reduces and eliminates subcutaneous abnormalities?" I asked. 
He winked at me. "It should work just fine." He glanced at the computer. "That's two hundred and eight."

"What?"

"It costs two hundred and eight dollars."

"Two hundred and eight?" I tried not to shout. "For that?" I pointed at the tiny white tube. "You've got to be kidding me. Two hundred and eight? That's insane!"

The pharmacist shrugged. "There's no generic."

I couldn't keep my eyes from filling with tears. I shrugged and picked up my purse. "I can't pay that."

"Ma'am?"

"I can't pay that." Turning around, I walked out.

Eliot and I stared into the hollow brown circles of our flat beers. We'd gone straight from the cvs to Club Tee Yee, a cheap local watering hole. I eyed the bar's white plastic cubbies of olives, lemons, and pearl onions.

"You think if we mashed up some olives into, like, a vodka paste you could smear it on the bridge of my nose?"

"I'd do that for you," Eliot said, gripping my hand beneath the peeling, gummy varnish of the bar counter.

"I'll probably be an exploited uninsured adjunct forever, you know," I added. "At least until they fire me, and I'm forced onto welfare."

"And I'll be a waiter at TGI Friday's. Or the sixty-eight-year-old guy in the vest sweeping up popcorn when you walk out of the Arclight."

"Will you bring home any cool stuff you find?"

He nodded and sipped. "Did I tell you Jeremy and Chris were put on furlough this week, too?"

I shook my head. "Are you kidding me?"

"They were the last holdouts at their firm. The principal architects pruned the workforce down from about eighty to ten, and now they're picking off the ten."

I took a swig. "I blame Dubai."

“I know, frickin' Dubai. Where's a floating Golden Palace Hotel when you need one?"

I pressed on the sore red spot on my nose.

"You should get the ointment."

I shook my head. 
"It's medicine. If there's anything you should spend money on, it's your health."

"It'll leave a hundred seventy-five dollars in my account."

"You should call Dr. Beau for some samples of the prescription."

"What if she's too busy drinking Diet Coke or Botoxing baby boomers?"

"Just call her, Jane."

I regripped Eliot's hand beneath the bar counter and squeezed. I'd always loved Eliot's hands. They were broad and even with smooth white nails, the fingertips blunted but gently rounding. They were hands that said I know how to carry things and I know how to build something very fine. I hated the idea of his elegant skills and capabilities going unutilized.

"I don't want to be this person," I said.

"What person?"

I shrugged. "This sour, tight, money-obsessed complaining person."

"You're not that person."

I nodded, even though I still felt a hollow black disappointment in my stomach. "I guess we just have to focus on the other things." I took a swig of my drink. "Bigger apartment, ixnay. Thriving career, adios."

"We'll be less distracted by the things that don't ultimately matter," he said. The bartender's back was turned, and Eliot plucked an olive out of the plastic white box. "-all the stuff, you know? Think of it that way." He placed the olive on the napkin in front of me.

"Cars, blenders, vacations on the Cape, Tupperware, hot tubs," I said. Then I looked at him, my eyes wide. "What if my unicorn horn really was the source of all my power? Of our power?"

Eliot rolled his eyes. "We have other sources of power."

"Flashy obvious sources that will allow us to buy a house some day and keep us insured?"

Eliot shook his head and kissed the back of my hand. "Probably not."

I glanced away from the counter toward the bar's cold, empty corners. Then, pressing down again on the depression in the bridge of my nose, I moved even closer to Eliot where he sat beside me in the warm yellow light of a single, hovering bulb. 